\title{
Bentuk Pergeseran Dialek pada Masyarakat Betawi
}

\author{
Riris Tiani \\ Fakultas Ilmu Budaya, Universitas Diponegoro \\ tiani.riris@gmail.com
}

\begin{abstract}
This research is related to sociolinguistic studies. The problem that emphasizes is the shift of the Betawi dialect in the family domain, especially the Betawi descendants who live in Jakarta. This study aims to determine the form of shifting Betawi dialect. Provision of data was taken using questionnaires and random interviews specifically aimed at some Betawi communities in the family domain. Then the data describe phenomenologically by looking at the basic principles of speech components as a reference for analysis. From the research that has been done, the results obtained that the dialect shift that occurs in Betawi occurs in the generation of children and parents, this form of shift can be identified in the use of shifting Betawi vocabulary into other vocabulary. Other languages are dominated by Indonesian, which indirectly is the second language of the Betawi community. While the causes of shifting dialects in the Betawi community include the influence of language variations and the lack of loyalty of the local community.
\end{abstract}

Key word: dialect shifting, Betawi dialect, speech component

\section{Intisari}

Penelitian ini terkait dengan kajian sosiolinguistik.Persoalan yang tekankan adalah pergeseran dialek Betawi pada ranah keluarga, terutama masyarakat keturuna Betawi yang tinggal di Jakarta.Penelitian ini bertujuan untuk mengetahui bentuk pergeseran dialek Betawi.Penyediaan data diambil menggunakan kuesioner dan wawancara secara acak bertujuan khusus pada sebagian masyarakat Betawi dalam ranah keluarga.Lalu data deskripsikan secara fenomenologis dengan melihat prinsip dasar komponen tutur sebagai acuan analisis. Dari penelitian yang sudah dilakukan, maka didapat hasil bahwa pergeseran dialek yang terjadi di Betawi terjadi pada generasi anak dan orang tua, bentuk pergeseran tersebut dapat diidnetifikasi pada penggunaan kosa kata Betawi yang bergeser menjadi kosa kata bahasa lain. Bahasa lain tersebut didominasi oleh bahasa Indonesia, yang secara tidak langsung itu sebagai bahasa kedua masyarakat Betawi. Sedangkan faktor penyebab pergeseran dialek di masyarakat Betawi antara lain adalah pengaruh variasi bahasa dan kurangnya loyalitas masyarakat setempat.

Kata kunci: pergeseran dialek, dialek Betawi, komponen tutur. 


\section{Pendahuluan}

Setiap bidang ilmu mempunyai kegunaan praktis.Begitu juga dengan ilmu Sosiolinguistik.Sosiolinguistik terdiri dari dua unsur sosio dan linguistik, yang berarti bahwa sosio merupakan kumpulan masyarakat dan linguistik merupakan ilmu tentang bahasa. Sumarsono (2012:11) mendefinisikan sosiolinguistik kajian tentang bahasa yang dikaitkan dengan kondisi masyarakat. Ahli lain menyebutkan bahwa sosiolinguistik studi bahasa berhubungan dengan penutur bahasa itu sebagai anggota masyarakat, Nababan (1998:2). Sociolinguistic is the study of language use within or among groups of speaker" (Wardhaugh, 2010:118). Dapat dikatakan bahwa sosiolinguistik mempelajari dan membahas aspek-aspek kemasyarakatan berhubungan dengan variasi sosial pada.

Sosiolinguistik memiliki cakupan ilmu yang luas, Nababan (1998:3) mengemjkakan tiga masalah pokok dalam kajian sosiolinguistik yaitu: mengkaji bahasa dalam konteks sosial dan kebudayaan, menghubungkan faktor kebahasaan, ciri dan ragam bahasa dengan situasi serta faktor sosial-budaya, serta mengkaji fungsi sosial bahasa dalam masyarakat.

Chaer dan Agustina (2004:5) merinci bahwa penelitian dalam ranah sosiolinguitik melibatkan beberapa unsur, di antaranya: identitas sosial dari penutur dan lawan tutur, lingkungan sosial terjadinya peristiwa tutur, yang meliputi suasana, tempat, dan konteks tuturan, yang semuanya disebut dengan komponen tutur.

Heterogenitas budaya yang ada di Nusantara disebabkan karena Indonesia merupakan Negara kepulauan.Sehingga perbedaan tempat berakibat terhadap perbedaan budaya.Pada tempat yang sam apun, tidak menutup kemungkina perbedaan budaya terjadi, hal ini diakibatka oleh gerak migrasi masyarakat.Gerak migrasi masyarakat terjadi karena kebutuhan beradaptasi terhadap kondisi lingkungan, sehingga menyebabkan masyarakat berbudaya dinamis.

Salah satu kota besar yang memiliki heterogenitas tinggi adalah kota Jakarta. Dalam perkembangan sejarahnya bernama Batavia atau Sunda Kelapa atau Jayakarta merupakan sebuah daerah pelabuhan sebagai tempat bertemunya para pedagang dari luar seperti bangsa Eropa, Cina, dan Arab.Oleh karena itu, percampuran berbagai budaya terjadi di Jakarta, termasuk bahasa. Bahasa Betawi berasal dari hasil percampuran antara bahasa Melayu dengan 
bahasa lainnya seperti bahasa Arab Mesir, bahasa Cina, dan bahasa Jawa yang tersebar di Indonesia bagian barat.

Muhajir (1984:5) secara garis besar menjelaskan Jakarta terbagi atas dua subdialek, yaitu subdialek Dalam Kota dan subdialek Pinggiran. Subdialek pinggiran sering juga disebut "Betawi Ora" sebutan tersebut muncul karena di daerah pinggiran kota, kata ora berasal dari bahasa Jawa. Kata ora sering dipakai berdampingan dengan kata kaga (tidak). Sebutan tersebut menggambarkan bahwa banyak terdapat kata-kata yang berasal dari bahasa Jawa, yang dipakai di pinggiran kota, dan tidak dipakai dalam subdialek Dalam Kota.

Masyarakat Jakarta secara alami terbentuk sebagai dwibahasawan. Bahwa seorang terlahir dilingkungan yang menggunakan dua bahawa sekaligus secara berdampingan sebagai identitas sosial dan membentuk komunitas untuk bekerja sama. Nababan (1998:5) yang mengatakan istilah kedwibahasaan biasanya dipergunakan untuk kemampuan dan kebiasaan menggunakan dua bahasa(multilingualism).Chaer dan Agustina (2004:177), menyebutkan bahwa pergeseran bahasa sebagai akibat dari mobilitas masyarakat yang tinggi.Sehingga dinamisme budaya dan bahasa sangat bergantung dari kuat atau tidaknya pengaruh di lingkungan atau keluarga. Pergeseran bahasa (language shift) menyangkut masalah penggunaan bahasa oleh seorang penutur atau sekelompok penutur yang bisa terjadi sebagai akibat perpindahan masyarakat tutur ke masyarakat tutur lain. Bahasa yang tergeser adalah bahasa yang tidak mampu mempertahankan diri (Sumarsono, 2012: 231).Pergeseran bahasa terjadi akibat dari pilihan bahasa dalam jangka panjang (paling tidak tiga generasi). Hal tersebut juga diungkapkan Fishman (1991:40) dalam kutipan berikut:

'Language shift is often a slow and cumulative process, therby making 'before vs after' data hard to come by. Rearly have competent and reasonably impartial observers been collecting the necessary diagnostic data over several years so that a detailed analysis can be made when and as needed".

Pergeseran bahasa merupakan proses yang lambat dan kumulatif, sehingga data sebelum atau sesudah pergeseran sulit didapat. Untuk mendapatkan data yang cukup dan kompeten analisis data diperlukan selama beberapa tahun.

Gejala-gejala yang menunjukan terjadinya pergeseran bahasa dan pemertahanan bahasa diamati dari berbagai ranah.Tanda awal pergeseran bahasa adalah adanya pergerakan 
satu bahasa baru ke ranah-ranah tertentu yang awalnya ditempati oleh bahasa lama. Sumarsono (2012: 235) mengemukakan faktor pendorong terjadinya pergeseran bahasa yaitu: Intergenerasi berhubungan dengan lebih dari satu generasi. Faktor ini dominan dalam kasus pergeseran bahasa.Pergeseran bahasa jarang terjadi pada sejumlah besar individu dalam suatu masyarakat, dengan menanggalkan bahasa dan mengganti dengan bahasa dalam kurun hidupnya selama tidak terjadi intergenerasi (Sumarsono, 2012:236). Faktor kedua adalah migrasi. Migrasi terjadi pada kelompok kecil bermigrasi ke daerah lain yang mengakibatkan bahasa mereka tidak dapat di mengerti di tempat baru. Dan, kelompok besar penutur bahasa bermigrasi ke sebuah wilayah kecil dengan sedikit penduduk, mengakibatkan penduduk setempat terpecah dan bahasanya tergeser.Ketiga faktor industrialisasi.Akibat dari kemajuan ekonomi dapat mengangkat posisi sebuah bahasa menjadi bahasa yang mempunyai nilai ekonomi tinggi.Misalnya bahasa Inggris, sebelum bahasa Inggris menjadi bahasa internasional bahasa yang digunakan untuk tingkat internasional adalah bahasa Latin.Semakin majunya perekonomian di Inggris yang ditandai oleh revolusi industri kemudian membuat orang beralih ke bahasa Inggris.Keempat faktor pendidikan.Sekolah menjadi salah satu faktor pergeseran bahasa, karena sekolah biasa mengajarkan bahasa asing kepada anak-anak, dengan demikian anak-anak menjadi dwibahasawan.Interkasi beragam juga terjadi di sekolah, sehingga pertemuan heterogenitas budaya dan bahasa di sekolah juga menjadi faktor pereseran bahasa di masyarakat.

Jakarta merupakan salah satu kota terpadat dengan tingkat heterogenitas yang tinggi. Oleh karena itu, dialek Jakarta telah mengalami interferensi dari bahasa Indonesia, misalnya kemakan (termakan), ketembak (tertembak), kecepetan (terlalu cepat).Heterogenitas yang terjadi karena mobilitas masyarakat yang tinggi, membuat dialek asli Jakarta (Betawi) mengalami pergeseran. Berdasar latar belakang tersebut, maka penelitian ini bertujuan untuk menemukan pola pergeseran dialek betawi dewasa ini menggunakan pendekatan sosiolingustik.

\section{Metode}

Penelitian ini menggunakan kajian sosiolinguistik.Jenis penelitian ini adalah penelitian kualitatif dengan pendekatan deskripsi fenomenologis.Bahwa data yang diambil melalui 
kuesioner dan wawancara pada ranah keluarga Betawi yang tersebar di Jakarta kemudian dideskripsikan sesuai dengan komponen tuturnya, guna didapat pola pergeseran dialek yang terjadi pada dialek Betawi di Jakarta. Informan yang digunakan adalah masyarakat kota yang terikat oleh satu geografik, misalnya tinggal di perumahan tertentu, dapat dilakukan klasifikasi berdasarkan stratifikasi sosial. Stratifikasi sosial dalam klasifikasi informan, dikelompokan berdasarkan pekerjaan, pendidikan, dan status dalam keluarga (ayah, ibu, dan anak) menggunakan metode purposive sampling.

\section{Pembahasan}

Pergeseran dialek Betawi dewasa ini menjadi ancaman bagi pemerhati budaya Betawi.Dialek tersebut mengalami penurunan pengguna. Berdasarkan temuan di lapangan, adanya pergeseran dialek karena berkurangnya peredaran kosakata Betawi. Berdasarkan jenisnya, pergeseran bahasa dibedakan menjadi dua macam, yaitu pergeseran bahasa sebagian dan pergeseran bahasa total. Pergeseran bahasa sebagian merupakan kepunahan bahasa yang masih merupakan proses, sedangkan pergeseran bahasa total adalah kepunahan bahasa.

1. Pergeseran Dialek Sebagian

\begin{tabular}{|c|c|c|}
\hline Konteks tuturan & Tuturan Dialek Betawi & Keterangan \\
\hline $\begin{array}{l}\text { Ayah sedang berbicara } \\
\text { kepada anaknya yang } \\
\text { terlihat makan berulang- } \\
\text { ulang }\end{array}$ & $\begin{array}{l}\text { + Lu mindo } \\
\text { _ ini baru mau makan }\end{array}$ & $\begin{array}{l}\text { mindo'kedua' bukan } \\
\text { berasal dari dialek Betawi, } \\
\text { melainkan dari dialek } \\
\text { Jawa. }\end{array}$ \\
\hline
\end{tabular}

Pergeseran dialek terjadi ketika ayah menyampaikan kata mindo ke anak. Sedangkan pemahaman anak, mindo berarti 'makan'. Padalah kata mindo bukan bermakna makan melainkan bermakna 'kedua' yang berasal dari bahasa Jawa. Pada generasi tersebut terlihat perbedaan pemahaman. Kata mindo ditengarai dari dialek Betawi yang berarti 'makan', padahal dari dialek betawi sendiri kata makan berarti garek. Sehingga dapat disimpulkan bahwa generasi anak di sini kurang menguasai kosa kata dialek betawi. 


\begin{tabular}{|l|l|l|}
\hline Konteks tuturan & Tuturan Dialek Betawi & Keterangan \\
\hline Anak sedang bertanya & + Mau kemane Be & kamarbukan berasal dari \\
kepada ayahnya tentang & - mau ke kamar dulu dah & $\begin{array}{l}\text { dialek Betawi, melainkan } \\
\text { dari bahasa Indonesia. }\end{array}$ \\
kondisi badan ayahnya & & \\
\hline
\end{tabular}

Pergeseran dialek terjadi pada penutur menggunakan kata kamar.Dalam dialek Betawi, tidak dikenal kata 'kamar'.Kata 'kamar' dalam dialek Betawi seharusnya disebut pangkeng. Ayah yang dalam hal ini sebagai penutur tidak menggunakan kata sesuai dengan kosa kata Betawi, mak dapat simpulkan bahwa pergeseran kata telah terjadi pada satu tingkat di atas Ego.

\begin{tabular}{|l|l|l|}
\hline Konteks tuturan & Tuturan Dialek Betawi & Keterangan \\
\hline Adik sedang berbicara & + Bang, menurut abang & cantik bukan berasal dari \\
kepada kakak berdiskusi & Raisa cantik kagak? & dialek Betawi, melainkan \\
kecil tentang kecantikan & - kalo die mah, kebangetan & dari bahasa Indonesia \\
seorang artis muda di & cantiknya. & \\
Indonesia & & \\
\hline
\end{tabular}

Pergeseran dialek terjadi pada penutur menggunakan kata cantik. Dalam dialek Betawi seharusnya disebut boto'.Penutur (kakak) tidak menggunakan kosa kata betawi asli dikarenakan sudah tidak menguasai lagi kosa kata tersebut.Sehingga dapat disimpulkan bahwa pergesaran kosa kata betawi sudah terjadi pada lingkungan anak ke anak.

\begin{tabular}{|c|c|c|}
\hline Konteks tuturan & Tuturan Dialek Betawi & Keterangan \\
\hline $\begin{array}{l}\text { Anak sedang berbicara } \\
\text { kepada } \\
\text { menyampaikan }\end{array}$ & $\begin{array}{l}+ \text { Mah, ini angkot jelek } \\
\text { banget ya. } \\
\text { _ Udeh diem aja, nyang }\end{array}$ & $\begin{array}{l}\text { Mah berasal dari bahasa } \\
\text { Asing. Sedangkan jelek } \\
\text { bukan murni berasal dari }\end{array}$ \\
\hline
\end{tabular}




\begin{tabular}{|l|l|l|}
\hline perasaannya tentang & penting ampek pasar. & dialek Betawi, melainkan \\
kondisi angkot yang anak & & dari kata 'buluk' yang \\
mengantar mereka pergi. & & berasal dari dialek Betawi. \\
\hline
\end{tabular}

Pergeseran dialek terjadi pada tataran anak ke orang tua.Terjadi pada kata sapaan untuk ibu yakni pada kata mah.Mah 'ibu', tidak dikenal dalam dialek Betawi, sapaan itu berasal dari bahasa Asing. Sedangkan sapaan mah sendiri dalam dialek Betawi berari enyak 'Ibu'.Lalu ada juga kata jelek.Dalam dialek Betawi tidak dikenal kata jelek. Kata jelek berasal dari bahasa Indonesia, namun mulai berkembang menjadi kosa kata pelengkap dalam dialek Betawi untuk menggantikan kata 'buluk'. Sehingga dapat disimpulkan bahwa penggunaan kosa kata asli Betawi secara perlahan mulai ditinggal oleh masyarakat penuturnya.Mulai dari generasi anak, kakak, dan orang tua.

\section{Pergeseran Dialek Total}

Pergeseran dialek total tidak ditemukan dalam ranah keluarga, lingkungan sosial yang terjadi pada berbagai generasi khususnya bagi masyarakat asli Betawi. Sebab, apabila pergeseran dialek total terjadi di berbagai lingkungan generasi pada masyarakat Betawi yang masih di Jakarta, maka hal itu akan berakibat hilangnya identitas budaya dan bahasa masyarakat Betawi pada generasi anak, kakak, dan orang tua.

\section{Faktor Penyebab Pergeseran Dialek}

a. Pengaruh Variasi Bahasa

Jakarta yang menjadi sentral budaya masyarakat, memiliki banyak permasalahan dalam proses pemertahanan budaya. Sebagai kota dengan heterogenitas masyarakat yang sangat tinggi, maka sangat berpotensi muncul variasi-variasi bahasa baru di lingkungan anak muda maupun orang tua pada berbagai kelas sosial. Variasi bahasa tersebut muncul karena keinginan setiap kelompok sosial untuk menonjol dan memberi identitas diri atas kelompok lain. Sehingga dibuatlah kode-kode dialek atau bahasa yang membuat orang lain di luar lingkungan sosial tersebut tidak mengerti dengan apa yang disampaikan. Oleh 
beberapa masyarakat Betawi khususnya dan luas umumnya, penggunanaan variasi bahasa yang baru mulai menjadi sebuah budaya baru yang berkembang secara pesat pada berbagai kelas sosial.Hal ini yang menyebabkan pergeseran dialek Betawi pada berbagai ranah.

b. Kurang Setia dengan Dialek

Melihat latar belakang masyarakat Betawi yang heterogen, hal ini juga berdampak pada psikologis masyarakat setempat, terutama pada loyalitas menggunakan dan mempertahankan dialeknya.Seperti yang telah diuraikan di atas, bahwa masyarakat asli Betawi berasal dari berbagai suku bangsa.Tinggal menyatu di daerah Betawi (Jakarta) secara turun menurut menjadi masyarakat asli Jakarta.

Kondisi ini tidak diimbangi oleh pembentukan kesadaran masyarakat terhadap loyalitas penggunanan bahasa atau dialeknya. Arus deras globalisasi budaya yang terjadi di Jakarta secara otomatis juga berdampak pada perubahan psikologis masyarakatnya. Di Jakarta, pintu masuk budaya-budaya dari luar sangat lebar, sedangkan tidak diimbangi oleh penguatan pengetahuan psikologis terhadap loyalitas budaya Betawi. Maka, hal ini menjadi masalah besar manakala masyarakat asli Betawi beralih untuk menerima bentuk variasi dialek dari luar yang dirasa mampu mewakili perasaan dan emosi mereka ketika berkomunikasi antarsesama dalam berbagai kelas sosial.

\section{Simpulan}

Pergeseran dialek Betawi dewasa ini menjadi makin meresahkan, terlihat dari analisis di atas bahwa pada berbagai generasi mengalami pergeseran dialek. Pergeseran dialek yang terjadi di Betawi terjadi pada generasi anak dan orang tua, bentuk pergeseran tersebut dapat diidnetifikasi pada penggunaan kosa kata Betawi yang bergeser menjadi kosa kata bahasa lain. Sedangkan faktor penyebab pergeseran dialek di masyarakat Betawi antara lain adalah pengaruh variasi bahasa dan kurangnya loyalitas masyarakat setempat. 


\section{Daftar Pustaka}

Chaer, Abdul dan Leonie Agustina. 2004. Sosiolinguistik: Perkenalan awal. Jakarta: Rineka Cipta.

Fishman, Joshua A. 1991. Reversing language Shift: Theoretical and Empirical Fondation of Assitance to Threatened Languages Multilingual Matter (Series).England: Multilingual Matters Ltd.

Nababan, P.W.J. 1998. Sosiolinguistik, Suatu Pengantar. Jakarta: Kesaint Blanc.

Muhajir.1984. Morfologi Dialek Jakarta Afiksasi dan Reduplikasi.Jakarta: Djambatan

Sumarsono. 2012. Sosiolinguitik. Yogyakarta: Pustaka Pelajar.

Wardhaugh, Ronald. 2010. An Introduction to Sociolinguistics Sixth Edition. United Kingdom: Wiley-Blackwell. 